\title{
TMPYP4 exerted antitumor effects in human cervical cancer cells through activation of p38 mitogen-activated protein kinase
}

\author{
Ming-Jun Cheng and Yun-Gui Cao*
}

\begin{abstract}
Background: The aim of the present study was to investigate the potential effects of the 5,10,15,20-tetrakis (1-methylpyridinium-4-yl) porphyrin (TMPyP4) on the proliferation and apoptosis of human cervical cancer cells and the underlying mechanisms by which TMPyP4 exerted its actions.

Results: After human cervical cancer cells were treated with different doses of TMPyP4, cell viability was determined by 3-(4,5-dimethyl-2-thiazolyl)-2,5-diphenyl-2-H-tetrazolium bromide (MTT) method, the apoptosis was observed by flow cytometry (FCM), and the expression of p38 mitogen-activated protein kinase (MAPK), phosphated p38 MAPK (p-p38 MAPK), capase-3, MAPKAPK2 (MK-2) and poly ADP-ribose polymerase (PARP) was measured by Western blot analysis. The analysis revealed that TMPyP4 potently suppressed cell viability and induced the apoptosis of human cervical cancer cells in a dose-dependent manner. In addition, the up-regulation of p-p38 MAPK expression levels was detected in TMPyP4-treated human cervical cancer cells. However, followed by the block of p38 MAPK signaling pathway using the inhibitor SB203580, the effects of TMPyP4 on proliferation and apoptosis of human cervical cancer cells were significantly changed.
\end{abstract}

Conclusions: It was indicated that TMPyP4-inhibited proliferation and -induced apoptosis in human cervical cancer cells was accompanied by activating the p38 MAPK signaling pathway. Taken together, our study demonstrates that TMPyP4 may represent a potential therapeutic method for the treatment of cervical carcinoma.

Keywords: TMPyP4, p38 MAPK, Human cervical cancer cells, Proliferation, Apoptosis

\section{Background}

Cervical cancer is the fourth common malignant tumor in women which leads to approximately 274,000 mortalities every year worldwide according to the reports of the World Health Organization (WHO) [1]. Notably, 85\% of cases and deaths occur in low- and middle-income countries [2]. Human papillomavirus (HPV) types is recognized as an essential precursor to the development of cervical cancer. The $\mathrm{WHO}$ has recommended the routine $\mathrm{HPV}$ vaccination in national immunization programmes

\footnotetext{
*Correspondence: yunguicao@sina.com

Department of Gynaecology, Shanghai Jiading District Maternal and Child Care Hospital, No. 1216, Gaotai Road, Jiading District, Shanghai 201821, China
}

worldwide. Early stage cervical cancer may be treated by triggering tumor cell apoptosis through the combined application of radiotherapy and chemotherapy [3]. However, patients with late-stage cervical cancer exhibit a poor physical condition, resulting in the limits of the application of radiotherapy, chemotherapy or the two therapies combined [4]. Currently, the pathogenesis of cervical cancer has not yet been completely understood, and there are no drugs available for effectively controlling the occurrence and development of this cancer [5]. So, it is urgent for us to seek new potential drugs and biomarkers for its diagnosis, prognosis, and therapy to improve clinical strategies of cervical cancer. 
The cationic porphyrin, 5,10,15,20-tetra-( $N$-methyl-4pyridyl) porphine (TMPyP4), a novel type of synthetic water-soluble photosensitizer, has been recently developed as a chemotherapeutics drug for treating cancers [6]. It has been reported that TMPyP4 leads to the arrest of tumor cell growth, and induces the apoptosis of tumor cells through reducing the telomerase activity [7-9], indicating that TMPyP4 presents a potential therapeutic target in tumor cells. Therefore, it is crucial to comprehensively understand biological effects of TMPyP4 in tumor cells before it can be used for anti-cancer therapeutics. In the present study, we evaluated the effects of TMPyP4 on the proliferation and apoptosis of human cervical cancer cells and further explored its underlying mechanisms.

\section{Methods}

\section{Cell culture}

Human cervical cancer cell line Hela and human normal cervical cells (Academia Sinica Cell Bank, Shanghai, China) were grown in low-glucose Dulbecco's modified Eagle medium (GibcoBRL, Grand Island, NY, USA) supplemented with $10 \%(\mathrm{v} / \mathrm{v})$ fetal bovine serum (SigmaAldrich Chemicals, USA), $100 \mathrm{IU} / \mathrm{mL}$ penicillin, and $10 \mathrm{mg} / \mathrm{mL}$ streptomycin. Cells were cultured in a incubator with $5 \% \mathrm{CO}_{2}$ at $37^{\circ} \mathrm{C}$.

\section{Cell viability assay}

Cell viability was assessed using MTT assay (Bestbio Biotechnology, Shanghai, China). Briefly, fresh human cervical cancer cells and human normal cervical cells at a concentration of $5 \times 10^{3}$ cells/well were seeded in 96-well flat-bottomed tissue culture plates (Corning Inc., Corning, NY, USA) with complete culture medium and incubated for $24 \mathrm{~h}$. Following two washes with phosphate-buffered saline (PBS), cells were incubated in $100 \mu \mathrm{L}$ culture medium containing $1,5,10$ or $20 \mu \mathrm{M}$ TMPyP 4 for $24 \mathrm{~h}$ at $37^{\circ} \mathrm{C}$ prior to the MTT assay. Then, a total of $10 \mu \mathrm{L}$ MTT and $100 \mu \mathrm{L}$ culture medium was added to each well, and incubated for $1 \mathrm{~h}$ at $37^{\circ} \mathrm{C}$. The optical densities of the samples were measured directly using a spectrophotometric microplate reader (Beyotime Institute of Biotechnology, Haimen, China) at a wavelength of $490 \mathrm{~nm}$. Each experiment was performed in triplicate and repeated six times.

\section{Cell apoptosis assay}

The apoptotic cells were identified by FCM according to the published article [10]. Human cervical cancer cells and human normal cervical cells at a density of $2 \times 10^{4} /$ $\mathrm{mL}$ were cultured in 10\% FBS-containing DMEM with $1,5,10$ or $20 \mu \mathrm{M}$ TMPyP4 for $24 \mathrm{~h}$, respectively. Cells were harvested and washed twice with cold PBS by gentle shaking. Resuspended cells were added to $1 \times$ binding buffer and cell density was adjusted to 200,000-500,000/ $\mathrm{mL}$. In the dark, $5 \mu \mathrm{L}$ of Annexin V-FITC (50 mM TRIS, $100 \mathrm{mM} \mathrm{NaCl}, 1 \% \mathrm{BSA}, 0.02 \%$ sodium azide, $\mathrm{pH} 7.4$ ) was added to the cell suspension in a mix of $195 \mu \mathrm{L}$ and incubated for $10 \mathrm{~min}$ at room temperature before adding $190 \mu \mathrm{L} 1 \times$ binding buffer and $10 \mu \mathrm{L}$ propidium iodide (PI). Cell apoptosis was assayed using a FACScan flow cytometry apparatus (BD Biosciences, San Jose, CA, USA) and the percentage of apoptotic cells was analyzed using FlowJo 7.6.1 software (TreeStar, Inc., Ashland, OR, USA). Each experiment was performed in triplicate and repeated six times.

\section{Western blot analysis}

Following the treatment with $20 \mu \mathrm{M}$ TMPyP4 for $24 \mathrm{~h}$, cells were collected for protein extraction. The examination of the expression levels of caspase-3, MK-2, PARP, p38 MAPK and p-p38 MAPK was then performed. Total protein was extracted and the bicinchoninic acid assay kit (Beyotime Institute of Biotechnology) was used to measure the protein concentration. A total of $20 \mu \mathrm{g}$ protein was separated by SDS-PAGE and transferred onto a polyvinylidene fluoride membrane using wet transfer apparatus (Bio-Rad, Hercules, CA, USA). The membranes were then blocked with 5\% skimmed milk and incubated overnight at $4{ }^{\circ} \mathrm{C}$ with the primary antibodies, followed by incubation with the secondary antibodies labeled with HRP. Next, the protein bands were visualized using an enhanced chemiluminescence kit (Millipore, Billerica, MA, USA) and the protein levels were detected using the chemiluminescence reader, ImageQuant $^{\mathrm{TM}}$ LAS4000 (GE Healthcare, Pittsburgh, PA, USA). Antibodies were purchased from Santa Cruz Biotechnology, CA, USA. Band density was quantitated using Image J software (Image J 1.35, National Institute of Mental Health, USA).

\section{Caspase- 3 activity assay}

Caspase-3 activity was analyzed using caspase- 3 activity assay kits according to the manufacturer's instructions. Briefly, the reaction buffer and the specific enzyme DEVD-pNA were added to each cell plate and further cultured in an incubator for $1 \mathrm{~h}$ at $37{ }^{\circ} \mathrm{C}$. The developed colorimetric reaction was measured at $405 \mathrm{~nm}$ in a 96-well Biorad 680 microplate reader (Bio-Rad, Hercules, CA, USA).

\section{Block of $\mathrm{p} 38$ MAPK signaling using inhibitor}

Cells were treated with p38 MAPK inhibitor SB203580 $(5 \mu \mathrm{M})$ for $24 \mathrm{~h}$ followed by addition of $20 \mu \mathrm{M}$ TMPyP4, and further incubated for $24 \mathrm{~h}$. Then, cell proliferation and apoptosis were evaluated. 


\section{Statistical analysis}

All results were analyzed using SPSS 17.0 statistical software (IBM, Armonk, NY, USA). Data are presented as the mean \pm standard deviation (SD). Student's two-tailed t test was used to determine the statistical differences between the treatment and control groups. P values were based on the two sided statistical analysis, and $\mathrm{P}<0.05$ was considered to indicate a statistically significant difference.

\section{Results}

TMPyP4 inhibited the proliferation rates of human cervical cancer cells

To investigate the roles of TMPyP4 in human cervical cancer cells, we performed the MTT assay to evaluate the changes of cell viability. It was found that TMPyP4 $\left(\mathrm{IC}_{50}=16.35 \mu \mathrm{M}\right)$ significantly decreased $\mathrm{OD}_{490}$ values of human cervical cancer cells in a dose-dependent manner compared with the control group without TMPyP4 treatment $(P<0.05)\left(\right.$ Fig. 1a). On the other hand, $\mathrm{OD}_{490}$ values
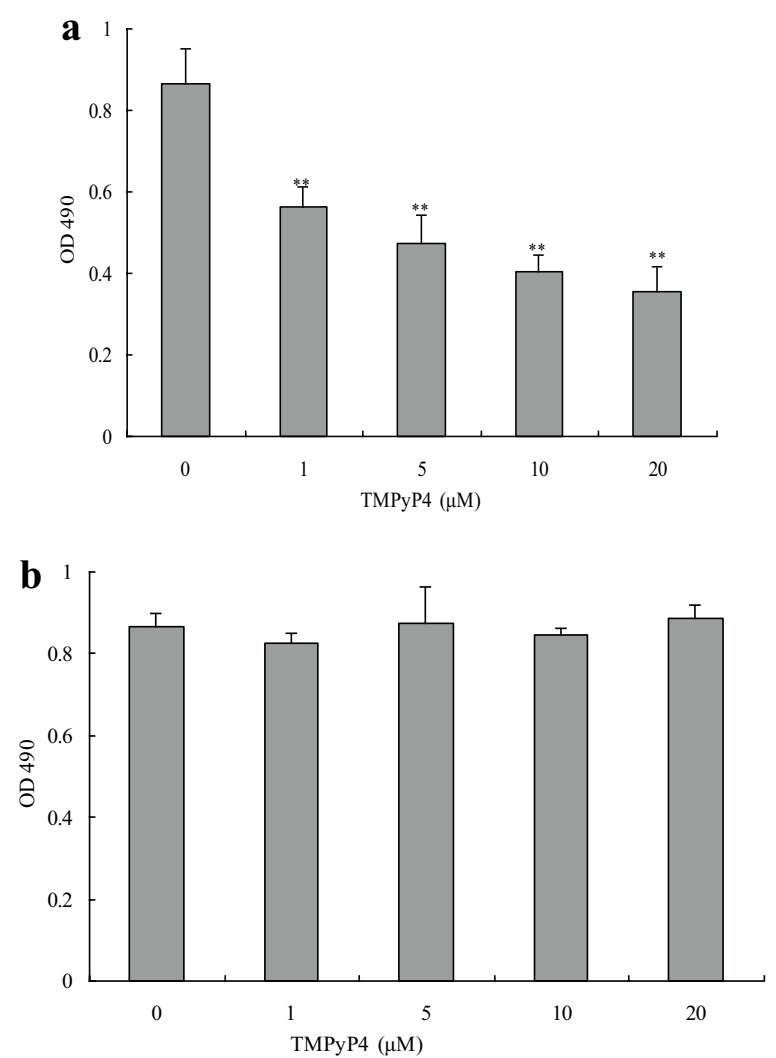

Fig. 1 TMPyP4 inhibited cell proliferation in human cervical cancer cells. After cells were treated with 1, 5, 10 or 20 MM TMPyP4 for $24 \mathrm{~h}$, cell proliferation in human cervical cancer cells (a) and human normal cervical cells $(\mathbf{b})$ was measured by MTT assay. Data are expressed as mean \pm SD of three independent experiments in six replicates. ${ }^{*} P<0.05$ or ${ }^{* *} P<0.01$ indicates significance, $P>0.05$ means no difference of human normal cervical cells were minimally affected after exposed to TMPyP4 at different concentrations $(P>0.05)$ (Fig. 1b). These results indicated that TMPyP4 had low cytotoxic effects on human normal cells and inhibited cell proliferation in human cervical cancer cells.

\section{TMPyP4 induced the apoptosis of human cervical cancer cells}

To evaluate the apoptotic effects of TMPyP4 on human cervical cancer cells, cells were respectively exposed to different concentrations of TMPyP4 for $24 \mathrm{~h}$. As shown in Fig. 2a, TMPyP4 remarkably induced the apoptosis of human cervical cancer cells in a dose-dependent manner. Approximately 9.0, 15.0, 36, 55.0\% of cancer cells occurred apoptosis respectively after exposed to $1,5,10$, $20 \mu \mathrm{M}$ TMPyP 4 for $24 \mathrm{~h}$, but less than $6.0 \%$ of cancer cells without TMPyP4 stimulation showed apoptosis. Next, to further ascertain the apoptotic effects of TMPyP4 on human cervical cancer cells, typical apoptotic marker caspase- 3 activity was measured by commercial kits. As shown in Fig. 2b, caspase-3 activity was promoted in TMPyP4-treated human cervical cancer cells $(P<0.05)$, which indicated that TMPyP4 indeed triggered apoptosis in human cervical cancer cells. Nevertheless, results in Fig. 2c provided the evidence that there was no significant apoptosis in human normal cervical cells after being exposed to the indicated concentration of TMPyP4 for $24 \mathrm{~h}(P>0.05)$. These findings suggested that TMPyP4 obviously induced apoptosis in human cervical cancer cells, but not in human normal cervical cells.

\section{TMPyP4 activated p38 MAPK signaling in human cervical cancer cells}

To determine the mechanisms underlying the promotion of cell apoptosis, we assessed the expression pattern of p38 MAPK signaling components including p38 MAPK and p-p38 MAPK by Western blot assay in human normal cervical cells and human cervical cancer cells (Fig. 3a). Western blot analysis of p38 MAPK found that p38 MAPK protein was expressed in human cervical cancer cells and human cervical cancer cells, but it showed no difference between TMPyP4 $(20 \mu \mathrm{M})$ treated cells and non-TMPyP4 treated cells $(P>0.05)$. Furthermore, there was no obvious changes in protein expression of p-p38 MAPK between TMPyP4-treated normal cells and the control normal cells $(P>0.05)$. In contrast, the p-p38 MAPK expression level was comparatively low in human cervical cancer cells compared with normal cells, and elevated protein level of p-p38 MAPK was demonstrated in TMPyP4-treated cells in comparison with cancer cells without TMPyP4 stimulation $(P<0.05)$ (Fig. $3 \mathrm{~b})$. It was suggested that TMPyP4 could activate the p38 MAPK signaling pathway in human cervical cancer cells. 

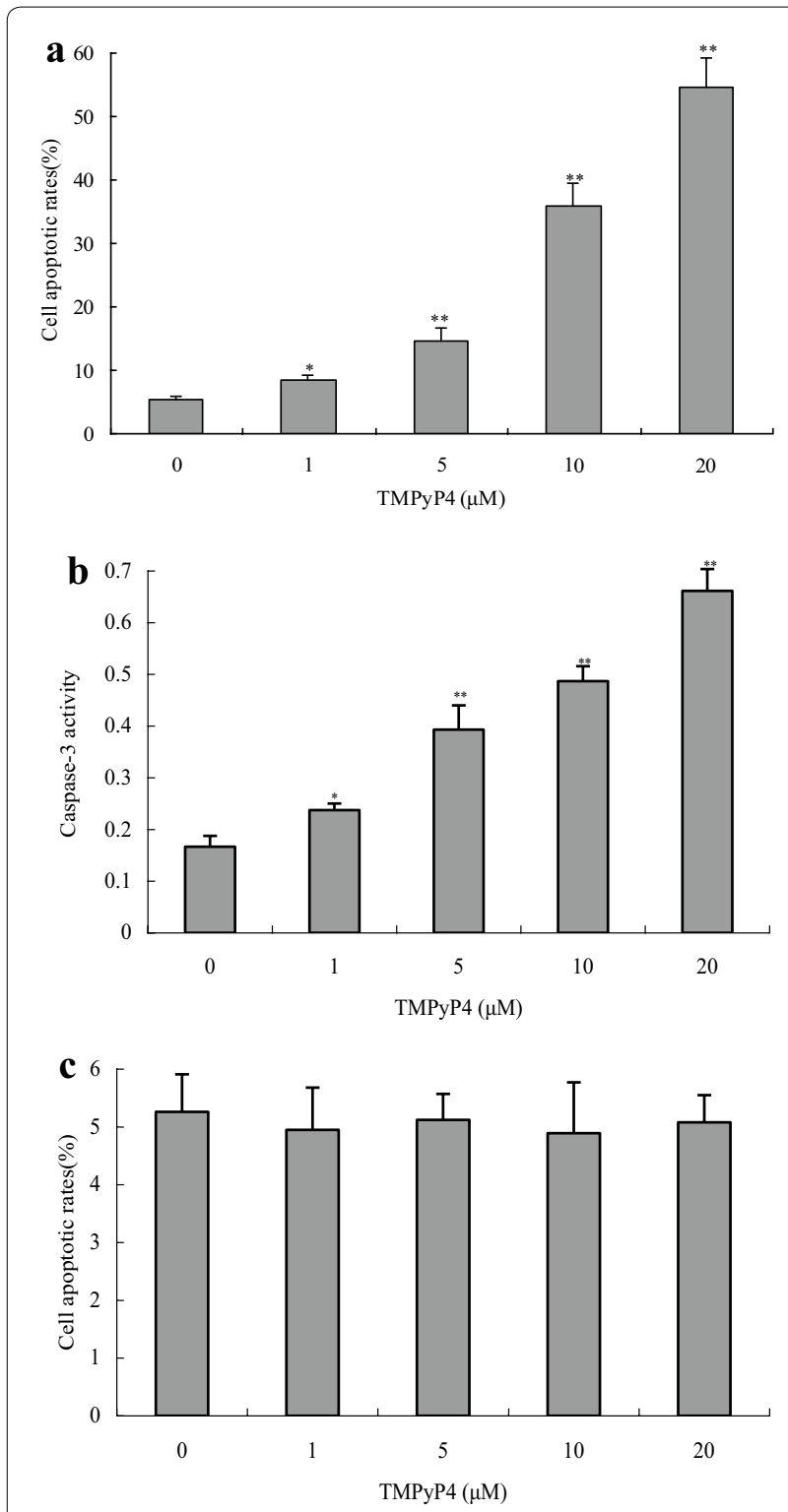

Fig. 2 TMPyP4 induced cell apoptosis in human cervical cancer cells. Human cervical cancer cells were treated with 1, 5, 10 or $20 \mu \mathrm{M}$ TMPyP4 for $24 \mathrm{~h}$, the apoptotic rates (a), and caspase- 3 activity $(\mathbf{b})$ in cells was determined. The apoptotic rates of human normal cervical cells treated with 1, 5, 10 or $20 \mu \mathrm{M}$ TMPyP4 for $24 \mathrm{~h}$ were tested by FCM (c). Data are expressed as mean \pm SD of three independent experiments in six replicates. ${ }^{*} P<0.05$ or ${ }^{* *} P<0.01$ indicates significance, $P>0.05$ means no difference

\section{Activation of p38 MAPK signaling in human cervical cancer cells is required for TMPyP4-induced down-regulation of cell viability}

Further, we examined the influence of p38 MAPK signaling on TMPyP4-induced down-regulation of cell viability in human cervical cancer cells. Cells treated with p38 MAPK signaling inhibitor SB203580 showed a decline

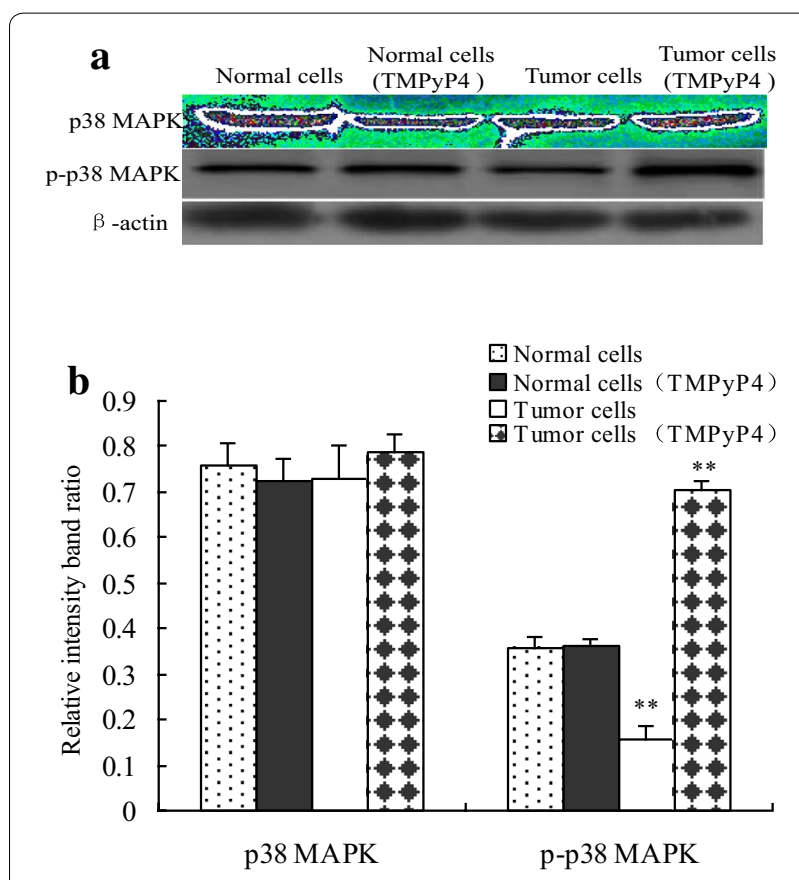

Fig. 3 TMPyP4 activated the p38 MAPK signaling pathway in human cervical cancer cells. Human cervical cancer cells or human normal cervical cells were treated with $20 \mu \mathrm{M}$ TMPyP 4 for $24 \mathrm{~h}$, the protein expression level of p38 MAPK and p-p38 MAPK was measured by Western blot (a). Band density was analyzed using Image J software (b). Data are expressed as mean \pm SD of three independent experiments in triplicate. ${ }^{*} P<0.05$ or ${ }^{* *} P<0.01$ indicates significance, $P>0.05$ means no difference

in MK-2 protein expression, but had no effects on p-p38 MAPK expression compared to the control cells (Fig. 4a), suggesting better inhibitory efficiency of SB203580. Cell viability was promoted showing as high $\mathrm{OD}_{490}$ values in SB203580-treated cells while it was inhibited in TMPyP4-treated cells compared to the control $(P<0.05)$. However, there was no difference in cell $\mathrm{OD}_{490}$ values between SB203580-TMPyP4 co-treated cells and SB203580 treated cells $(P>0.05)$ (Fig. 4b).

\section{Activation of p38 MAPK signaling in human cervical cancer cells is required for TMPyP4-triggered apoptosis}

To further confirm whether p38 MAPK activation contributed to TMPyP4-triggered apoptosis in human cervical cancer cells, a pharmacological inhibitor of p38 MAPK, SB203580 was used in this study. It was found that pretreatment of $5 \mu \mathrm{M}$ SB203580 remarkably attenuated the apoptotic rate (Fig. 5a) and caspase-3 activity (Fig. 5b), while TMPyP4 significantly induced apoptosis by promoting the apoptotic rate, caspase-3 activity, and PARP and caspase-3 protein expression (Fig. 5c) in human cervical cancer cells $(P<0.05)$. Moreover, the apoptotic rate, caspase- 3 activity, caspase- 3 and 


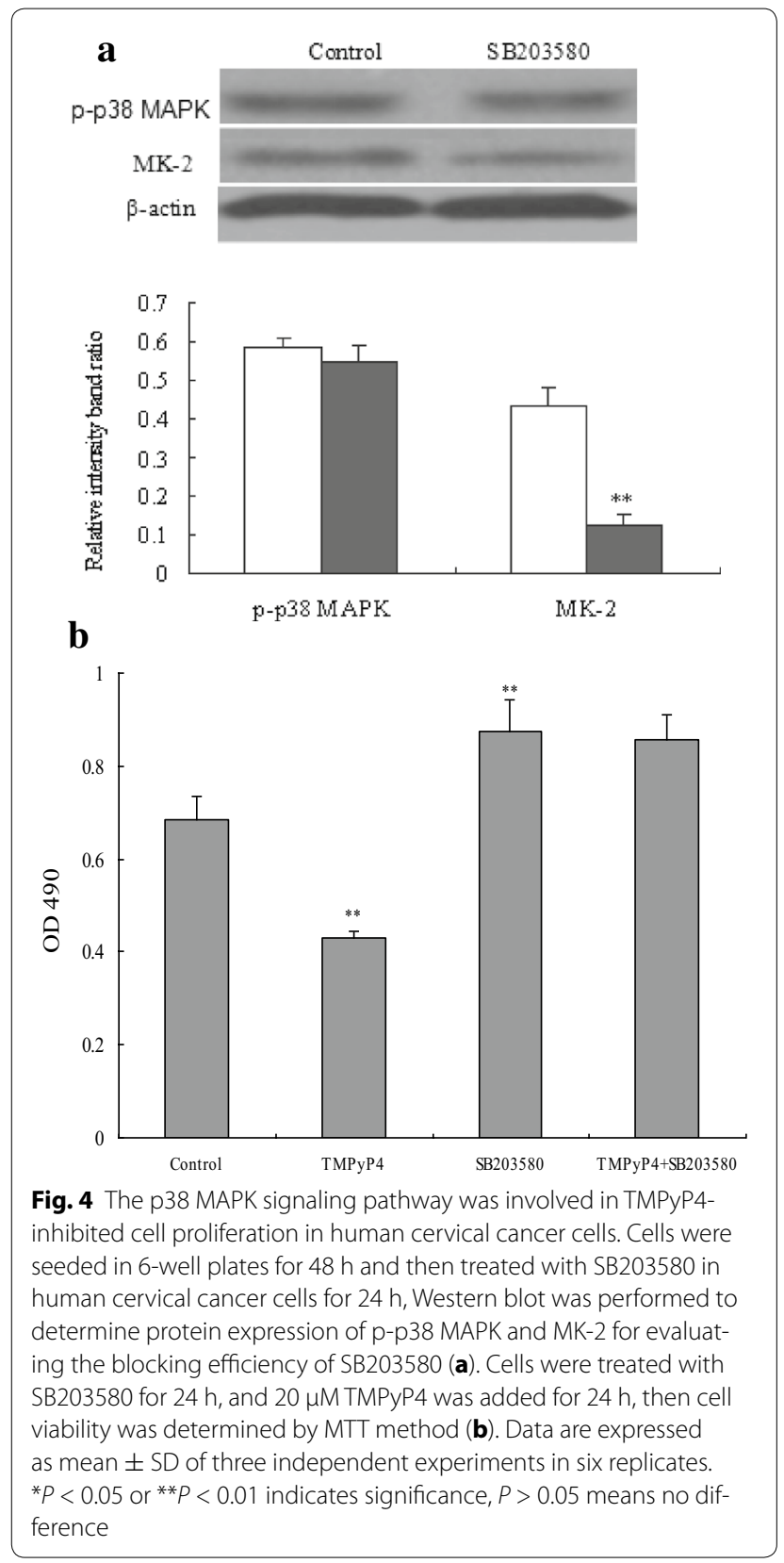

PARP protein expression showed no difference between SB203580-treated cells and SB203580-TMPyP4 cotreated groups $(P>0.05)$. These results indicated that p38 MAPK activation was involved in TMPyP4-induced apoptosis in human cervical cancer cells.

\section{Discussion}

TMPyP4, serving as a photosensitizer in PDT, has proved to play an essential role in controlling osteosarcoma [11]. Besides, TMPyP4 has been recently developed as a chemotherapeutics drug to inhibit telomerase activity through
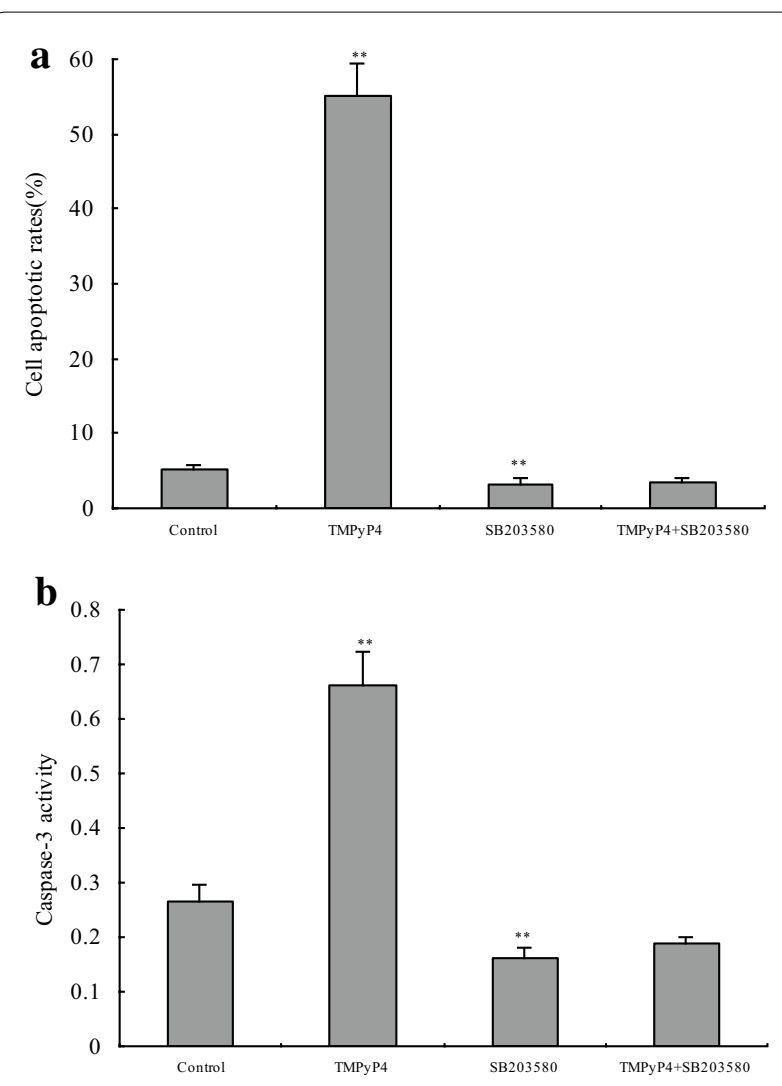

c

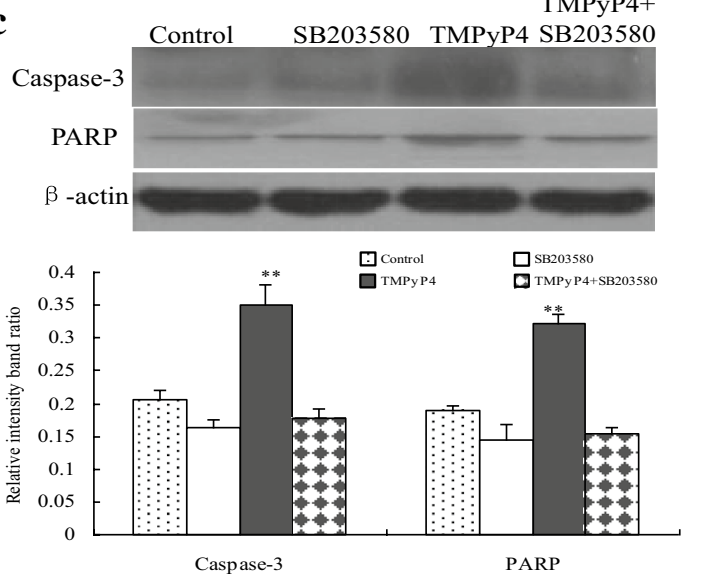

Fig. 5 The p38 MAPK signaling pathway was involved in TMPyP4triggered cell apoptosis in human cervical cancer cells. Cells were treated with SB203580 for $24 \mathrm{~h}$, and $20 \mu \mathrm{M}$ TMPyP4 was added for $24 \mathrm{~h}$, then cell apoptotic rates (a), caspase-3 activity (b), PARP and caspase-3 protein expression (c) were measured. Data are expressed as mean \pm SD of three independent experiments in six replicates. ${ }^{*} P<0.05$ or ${ }^{* *} P<0.01$ indicates significance, $P>0.05$ means no difference

binding to and stabilizing telomeric G-quadruplex DNA in cancer cells [7-9]. Through directly interaction with telomeres, TMPyP4 can rapidly evoke antiproliferative 
effects [12]. In vivo, after intratumor injection of $10 \mathrm{mg} /$ kg TMPyP4 for 10 days, cervical tumor growth in nude mice was significantly inhibited without any injury to the skin and internal organs [13]. Therefore, in this study, we used this agent for investigation in cultured human cervical cancer cells to further evaluate its antitumor effects and underlying mechanism.

In the present study, treatment with various concentration of TMPyP4 significantly induced inhibition of proliferation in human cervical cancer cells. Previous report suggested that TMPyP4 could lead to progressive telomere shortening that eventually resulted in cancer cell apoptosis [6]. Mikami-Terao et al. ever demonstrated that treatment with $100 \mu \mathrm{M}$ TMPyP4 significantly inhibited the growth of K562 leukemic cells, with decreases of cells in the G(1) phase and increases of those in the $S$ and $G(2) / M$ phases after $48 \mathrm{~h}$ [14]. In the following study, Mikami-Terao and his team found that TMPyP 4 at doses of $10,20,50$ or $100 \mu \mathrm{M}$ significantly inhibited the growth of retinoblastoma cell lines, Y79 and WERI-Rb1 cells. In contrast, cell apoptosis was induced by TMPyP4 in a dose-dependent manner in both cell lines, which was associated with the increased expression of phosphorylated p53 (Ser46) protein and activation of MAPK [15]. TMPyP4 at concentrations of $3,6,15,30$ or $60 \mu \mathrm{M}$ significantly inhibited the proliferation and motility of human ovarian carcinoma A2780 cells but suppressed the expression levels of minichromosome maintenance protein-2 (MCM2) and carbonic anhydrase IX (CA-IX) [16]. Additionally, TMPyP4 inhibited proliferation while induced apoptosis in colon cancer cells SW480 by the suppression of Wnt/ $\beta$-catenin signaling pathway [17]. More recently, a study demonstrated that, TMPyP4 at low doses less than $0.5 \mu \mathrm{M}$ could promote the migration of human lung cancer A549 cells, HeLa, osteosarcoma U2OS and SAOS2. In contrast, TMPyP4 at high-dose larger than $2 \mu \mathrm{M}$ inhibited cell proliferation and induced cell apoptosis in these cells [18]. These findings above provided new insights into TMPyP4 which could be developed as a possible anticancer drug.

Numerous studies have indicated that the mitogenactivated protein kinase (MAPK) signaling pathway plays an important role in regulating cell proliferation, promoting cell cycle progression [19-21], and inducing resistance to radiotherapy and chemotherapy in tumor cells [22, 23]. In addition, p38 MAPK signaling cascade is a major pathway participating in the apoptotic pathway to suppress apoptosis of tumor cells [24, 25]. For instance, K562 leukemic cells treated with $100 \mu \mathrm{M}$ TMPyP4 showed a decrease in c-Myc protein expression, and an obvious increase in the expression of p21 (CIP1), p57 (KIP2), p38 MAPK, c-Jun N-terminal kinase, and extracellular signal-regulated kinase [14]. Most interestingly, our data showed that TMPyP4 could promote the expression level of p-p38 MAPK in human cervical cancer cells, implicating p38 MAPK activation as a potential target for TMPyP4. Also, we provided the evidence that the p38 MAPK signaling was involved in TMPyP4-indcued changes in proliferation and apoptosis of human cervical cancer cells.

\section{Conclusions}

In conclusion, we not only revealed a critical role for TMPyP4 in human cervical cancer cell proliferation and apoptosis, but also explored the molecular mechanisms by which TMPyP4 contributed to its antitumor effects. Up-regulation of the p38 MAPK signaling pathway by TMPyP4 could inhibit cell proliferation while promoted cell apoptosis in human cervical cancer cells. This study provided insight into the molecular mechanism of the antitumor effects of TMPyP4, indicating the p38 MAPK signaling might be a potential therapeutic target for TMPyP4 in human cervical cancer.

\section{Authors' contributions \\ CYG was the guarantor of integrity of the entire study and was responsible for manuscript review. CMJ designed this study and took experimental studies. \\ Both authors read and approved the final manuscript.}

\section{Competing interests}

The authors declare that they have no competing interests.

\section{Availability of data and materials}

The datasets used and/or analysed during the current study are available from the corresponding author on reasonable request.

\section{Funding}

This article was supported by the grants from the National Natural Science Foundation of China (The research on Rac 1-regulated ESCs functions during wound healing, Grant No.: 81301639) and Chongqing Science and Technology Project (Grant No.: cstc2013jcyjA10138).

\section{Publisher's Note}

Springer Nature remains neutral with regard to jurisdictional claims in published maps and institutional affiliations.

Received: 13 March 2017 Accepted: 21 June 2017

Published online: 03 July 2017

\footnotetext{
References

1. Crosbie EJ, Einstein MH, Franceschi S, Kitchener HC. Human papillomavirus and cervical cancer. Lancet. 2013;382:889-99.

2. Campos NG, Sharma M, Clark A, Kim JJ, Resch SC. Resources required for cervical cancer prevention in low- and middle-income countries. PLoS ONE. 2016;11(10):e0164000.

3. Arbyn M, Castellsagué X, de Sanjosé S, Bruni L, Saraiya M, Bray F. Worldwide burden of cervical cancer in 2008. Ann Oncol. 2011;22(12):2675-86.

4. Kodama J, Seki N, Masahiro S, Kusumoto T, Nakamura K, Hongo A, Hiramatsu Y. Prognostic factors in stage IB-IIB cervical adenocarcinoma patients treated with radical hysterectomy and pelvic lymphadenectomy. J Surg Oncol. 2010;101:413-7.
} 
5. Torre LA, Bray F, Siegel RL, Ferlay J, Lortet-Tieulent J, Jemal A. Global cancer statistics, 2012. CA Cancer J Clin. 2015;65(2):87-108.

6. Fujimori J, Matsuo T, Shimose S, Kubo T, Ishikawa M, Yasunaga Y, Ochi M. Antitumor effects of telomerase inhibitor TMPyP4 in osteosarcoma cell lines. J Orthop Res. 2011;29:1707-11.

7. Grand CL, Han H, Muñoz RM, Weitman S, Von Hoff DD, Hurley LH, Bearss DJ. The cationic porphyrin TMPyP4 down-regulates C-MYC and human telomerase reverse transcriptase expression and inhibits tumor growth in vivo. Mol Cancer Ther. 2002;1:565-73.

8. Rha SY, Izbicka E, Lawrence R, Davidson K, Sun D, Moyer MP, Roodman GD, Hurley L, Von Hoff D. Effect of telomere and telomerase interactive agents on human tumor and normal cell lines. Clin Cancer Res. 2000;6(3):987-93.

9. Shammas MA, Shmookler Reis RJ, Akiyama M, Koley H, Chauhan D, Hideshima T, Goyal RK, Hurley LH, Anderson KC, Munshi NC. Telomerase inhibition and cell growth arrest by G-quadruplex interactive agent in multiple myeloma. Mol Cancer Ther. 2003;2(9):825-33.

10. Xia ZX, Li ZX, Zhang M, Sun LM, Zhang QF, Qiu XS. CARMA3 regulates the invasion, migration, and apoptosis of non-small cell lung cancer cells by activating NF-KB and suppressing the P38 MAPK signaling pathway. Exp Mol Pathol. 2016;100(2):353-60.

11. Mergny JL, Hélène C. G-quadruplex DNA: a target for drug design. Nat Med. 1998;4(12):1366-7.

12. Izbicka E, Wheelhouse RT, Raymond E, Davidson KK, Lawrence RA, Sun $D$, Windle BE, Hurley LH, Von Hoff DD. Effects of cationic porphyrins as $\mathrm{G}$-quadruplex interactive agents in human tumor cells. Cancer Res. 1999;59(3):639-44.

13. Liu AH, Sun X, Wei XQ, Zhang YZ. Efficacy of multiple low-dose photodynamic TMPYP4 therapy on cervical cancer tumour growth in nude mice. Asian Pac J Cancer Prev. 2013;14(9):5371-4.

14. Mikami-Terao Y, Akiyama M, Yuza Y, Yanagisawa T, Yamada O, Yamada H. Antitumor activity of G-quadruplex-interactive agent TMPyP4 in K562 leukemic cells. Cancer Lett. 2008:261(2):226-34.

15. Mikami-Terao Y, Akiyama M, Yuza Y, Yanagisawa T, Yamada O, Kawano T, Agawa M, Ida H, Yamada H. Antitumor activity of TMPyP4 interacting G-quadruplex in retinoblastoma cell lines. Exp Eye Res. 2009;89(2):200-8.
16. Liu H, Lv C, Ding B, Wang J, Li S, Zhang Y. Antitumor activity of G-quadruplex-interactive agent TMPyP4 with photodynamic therapy in ovarian carcinoma cells. Oncol Lett. 2014;8(1):409-13.

17. Zhang YQ, Zhang YH, Xie J, Li MN, Liu ZR, Shen JY, Shi SS, Lan XY, Wang $S$, Cheng NL. TMPyP4-regulated cell proliferation and apoptosis through the Wnt/ $\beta$-catenin signaling pathway in SW480 cells. J Recept Signal Transduct Res. 2016;36(2):167-72

18. Zheng XH, Nie X, Liu HY, Fang YM, Zhao Y, Xia LX. TMPyP4 promotes cancer cell migration at low doses, but induces cell death at high doses. Sci Rep. 2016;6:26592.

19. Browne AJ, Göbel A, Thiele S, Hofbauer LC, Rauner M, Rachner TD. p38 MAPK regulates the Wnt inhibitor Dickkopf-1 in osteotropic prostate cancer cells. Cell Death Dis. 2016;7:e2119.

20. Lin Y, Mallen-St Clair J, Wang G, Luo J, Palma-Diaz F, Lai C, Elashoff DA, Sharma S, Dubinett SM, St John M. p38 MAPK mediates epithelial-mesenchymal transition by regulating $\mathrm{p} 38 \mathrm{IP}$ and snail in head and neck squamous cell carcinoma. Oral Oncol. 2016;60:81-9.

21. Zhang C, Shi J, Mao SY, Xu YS, Zhang D, Feng LY, Zhang B, Yan YY, Wang SC, Pan JP, Yang YP, Lin NM. Role of P38 MAPK in enhanced human cancer cells killing by the combination of aspirin and ABT-737. J Cell Mol Med. 2015;19(2):408-17.

22. Liu CL, Chen SF, Wu MZ, Jao SW, Lin YS, Yang CY, Lee TY, Wen LW, Lan GL, Nieh S. The molecular and clinical verification of therapeutic resistance via the p38 MAPK-Hsp27 axis in lung cancer. Oncotarget. 2016;7(12):14279-90

23. Park SH, Seong MA, Lee HY. p38 MAPK-induced MDM2 degradation confers paclitaxel resistance through p53-mediated regulation of EGFR in human lung cancer cells. Oncotarget. 2016;7(7):8184-99.

24. Hui K, Yang Y, Shi K, Luo H, Duan J, An J, Wu P, Ci Y, Shi L, Xu C. The p38 MAPK-regulated PKD1/CREB/BCl-2 pathway contributes to seleniteinduced colorectal cancer cell apoptosis in vitro and in vivo. Cancer Lett. 2014;354(1):189-99.

25. Martin-Blanco E. p38 MAPK signalling cascades: ancient roles and new functions. BioEssays. 2000;22:637-45.

\section{Submit your next manuscript to BioMed Central and we will help you at every step:}

- We accept pre-submission inquiries

- Our selector tool helps you to find the most relevant journal

- We provide round the clock customer support

- Convenient online submission

- Thorough peer review

- Inclusion in PubMed and all major indexing services

- Maximum visibility for your research

Submit your manuscript at www.biomedcentral.com/submit
O) BioMed Central 